\title{
PROBLEMS OF DIGITAL PERCEPTION AND PRESERVATION OF LIVING CULTURAL HERITAGE IN BULGARIAN CHRISTIAN RELIGIOUS PRACTICES
}

\author{
Liana Galabova \\ lianagalabova@abv.bg
}

Independent Researcher, Sofia, Bulgaria

\begin{abstract}
Contemporary technological mediation of the perceiving of Christian religious practices raises new questions of cultural interpretation, related to re-conceptualisation of participation in church life and belonging to Bulgarian traditional confessions. Unpopularity of cultural value of documenting of living religious heritage creates polemics about the opportunity of photographing and filming in sacred spaces, exposing of observed church events in media and direct transmission from sacral sites also during creation of church art and practicing of other religious rituals. Therefore attempts to balance ethnic, confessional and liturgical dimensions with tourist and public interests in accordance to global development of that discussion and potential effects of stability or instability of emerging new traditions, deserve scholarly attention.
\end{abstract}

Keywords: Digitalisation; Living Heritage; Christianity; Religious Practices; Heritage Perceiving; Heritage Preservation; Church Arts

\section{ПРОБАЕМИ НА АИГИТААНОТО ВЪЗПРИЕМАНЕ И СЪХРАНЕНИЕ НА ЖИВОТО КУАТУРНО НАСАЕАСТВО В БЪАГАРСКИТЕ ХРИСТИЯНСКИ РЕАИГИОЗНИ ПРАКТИКИ'}

\author{
Аиана Гъ^ьбова
}

Изследовател на свободна практика, Софиия, Бьлгария

Резюме: Съвременното технологично опосредствяване на възприемането на християнските религиозни практики поставя проблеми на културната интерпретация свързани с реконцептуализирането на участието в църковния живот и принацлежността към традиционните у нас вероизповеАания. Непопулярността на културната ценност на Аокументирането и Аигитализирането на живото религиозно наслеАство съзАава полемика около възможността за фоотографиране и видеозаснемане в свещените пространства, за експониране на

' Статията публикува резултати от Аоклал, преАставен в рамките на конореренция LCH 2019 
наблюАавани църковни събития в меАиите и Аиректно излъчване от сакралните обекти и по време на съзАаване на църковно изкуство или практикуване на Аруги религиозни ритуали. Научен интерес заслужават опитите $а$ с се балансират етичните, вероизповеАни и митургични измерения с туристическите и обществени интереси в съответствие с глобалното развитие на тази Аискусия и потенциалните ефекти на устойчивост или нестабилност на възникващите нови тралиции.

КАючови Ауми: Аигитализация; Живо наслеАство; Християнство; Религиозни практики; Възприемане на наслеАството; Съхранение на наследството; Църковни изкуства

Анес християнските религиозни практики се възприемат и съхраняват, организират и осъществяват с помощта на техника и меАии. Аигитализацията на живото културно наслеАство на цьрквите е израз на стремежа $\Delta$ а се узнае всичко за тайнствения свят на религията и $\Delta$ а се зафриксира живот, който от еАна страна тьрси легитимация чрез публичност, а от Аруга страна не винаги е Аостьпен и споделен с обществеността. За съвременната реалност това напомня на рекламна стратегия сьздаваща илюзия за екзотичност, тълкува се като съображения за сигурност или се приема за неувереност изАаваща отсъствие на комуникативни умения и нагласи.

Проблемите на Аигитализацията възприемана като изява или регистрация са по-схолни с творчеството и организацията, откьАето илват най-Аобрите решения избягващи орормализма и пристрастността.

Сътрудничеството и квалифоикацията на специалисти от богословската и реАица нови културни области И икономически отрасли поставя нови теоретични и практически проблеми на Аинамичната интерпретация и реконцептуализиране на боговАъхновения човешкия фактор в религиозно-общностния (цьрковен) и социален живот и приналлежността към традиционните у нас вероизповедания.

Реалностите като роботизацията и интернет на нещата опосредствяват въпросите: Аали може и трябва ^и, защо, какво, как и АОколко Аа се наблюАава, Аокументира и отразява, как Аа се вмести техниката в сакралния интериор, как служителите на медиите да съчетават мобре ролите си на отразяващи и участващи в 
богослужението, богомолци и журналисти, профресионално ^и $А$ се

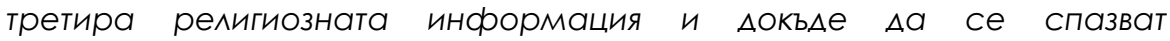
гражАанските права и правила, по съвест и по зальлжение.

Технологичните иновации често обезсмислят някои от тези вьпроси, Ауховенството намира канонични решения и както при електрификацията и канализацията на светите места преди голини, акцентьт отново се завръща на естеството на Ауховния живот и свързаните c него предизвикателства. Неизменното Ауховно ориентиране на религиозния живот изисква специално отношение към сакралните елементи на християнското живо наслеАство, които са част от традиционните български вероизповеАни практики. Това изисква колкото е възможно по-мащабно, Аетайлно и комплексно Аокументиране с цел $А а$ се съхрани това, което все още полиежи на възприемане и практикуване $\triangle \mathrm{HeC}$.

В миналото има периоли, през които Аостьпьт Ао сакралните пространства е бил ограничен, вьзпрепятстван или непопулярен. За това ни напомнят множеството указания за прави^а на поведение, които са част от пьрвото впечатление при досега сьс свети места (Фиг. 2, 4, 5, 6, 7). А лнес все още има храмове и обители, които са изоставени в руини или приналмежат кьм обезлюАени райони и места, кьАето архитектурното наслеАство е пол^ожено на риск от разпалане и разграбване. При щастлив случай на благоустрояване, пьрвите виАими промени са огралите, заключването и въвежлане на прави^а, преди още $л а$ се помисли за възстановяване на светостта на мястото и неговото обитаване, освен като охрана. Възможността изоставените сакрални паметници някога да са били поне частично документирани заелно с хората и живота по техните места, все още не означава наличната инорормация за тях $\Delta \mathrm{a}$ е Аостьпна и $\Delta \mathrm{a}$ може ефрективно $\Delta \mathrm{a}$ 
съхрани паметта за това местно наследство, която има стойност на възстановка 2 .

3а съвременните хора естествено възникват въпросите за целесьобразността на: реконструирането на сакрални обекти, учредяването на кондесионални общности, публична изява на вярващи инАивиАи, както и на богослужение без хора или като туристическа атракция. В името на тралицията и приемането на архаизма като ценност на опазването на автентичността ${ }^{3}$, Аигитализирането и популяризирането са съществени, защото те разпространяват благовестието, заколирано в живо слово и Аруги равноценни изразни средства. МежАу християнските вероизповедания има основни културно-орормиращи разлики на разбиране и преживяване на живото наследство акцентиращи на словото, Аитургичните Аействия, емоциите или почитането на светии, икони и мощи, затова и границата межАу нематериалните и материални носители на тралициите варира.

Аипсата на ясни утвърдени религиозни правила за възприемане и съхранение (Таблица 1) на живото културно наслелство в българските християнски практики налага необходимостта от непрекъснато позоваване на някакъв външен опит. Познаването на световните или Аруги местни практики граничи С налконфеесионален или налрелигиозен обмен, както и със заимстване на граждански, езотерични или еклектични обичай, непривични принципи и

2 Илеята за културната равностойност на все по-Аобре Аокументирани и проучени исторически места, сьпоставена с нецелесьобразността от запазването и възстановката на неАвижимото материално наслеАство извън автентичния им контекст и без общностите, които са ги съзАали и обитавали в миналото, вж. Заравненото минало. (Кьм историята на еАин терен в кв. "Княжево") - МАРИЯ МИТЕВА. В: "90 г. Регионален исторически музей на Софрия", 2018 г.

3 Вк^ючително Ауховната практика на Свещеното Предание на цьрквата като еАна от формите на божествено откровение.

4 За отАелната общност те могат да се обозначат Аискриминативно като: ненужни, ексцентрични, безсмислени, неуместни, неетични, новаторски, модернистични, икуменически, еретически или инославни, иноверни, атеистични, светски, езически, в зависимост от това Ао каква степен засягат специфичните религиозни чувства и интереси и крият риск от вероизповеАна Аезориентация. 
непри^ожима към местните условия регламентация. Особеностите на тези процеси варират спореА вероизповеданието, народопсихологията и сьчетанието от разно-образни Ауховни нагласи и съвременна културна Аинамика, но у нас за православието са волещи практичността, умереноста, импровизацията и Аистанцираното уважение към цьрковната институция, съчетано с Аоброжелателна критика. Високото ниво на инорормираност за аналогични местни практики свързани с българските празници понижава вероятността от Авупосочно отричане на християнската насоченост на релица събития извън глобалните им комерсиални варианти и в интерес на туристическия им и цьрковен потенциал, когато те се реализират в характерната си тралиционна форорма.

Проблемите на Аигиталното възприемане и съхранение на религиозната информация като живо наслеАство, обикновено стоят слел въпросите за наличието на транспорт, паркинг, комуникации,, охрана, рампа, асансьор, климатик, бюорет, санитарен възел, МеАИЦИнски ПУнкт, място за отАих И Аруги нормални елементи на обществени сгради и туристически обекти (Nikolov, 2018). Безопасността и улобството на поклонниците Анес вече не са само ми^осърАие или ^укс и не винаги се свежлат Ао традиционните: пейка, сянка и чешма... , но и не могат $а$ а се очакват в частен $А$ см, както са замислени и устроени някои свети места. Туристическата реалност изисква Аокументиране пьрво на тази обща ситуация и публикуване на общодостьпни Аанни за ритьма на живот на $а$ аено място, който преАи се изчерпваше с няколко категории: Аействащ, недействаш, с и без монаси и свещенослужители, отваря се на празник или само на събора.

Важно е тази поклонническа инорормация да е директна (Petkova, 2013), Аостоверна и преживяна, а пристрастността ѝ е среА положителните качества, когато става дума за пьтешествия. Вероятно може $\Delta$ a се открие и по-притеснителна ситуация от празничното и Аелничното ежеАневие на всяка цьрковна общност и ^окация от това наосът $\Delta а$ е изпьлнен с поставена на огромно скеле телевизионна или Аруга техника, ограждения със столове за офрициални гости, мощни 
калорифери среА народа или газово отоп^ение в купола, полицейски пропусквателен режим още на разклона на шосето, на входа на Авора или сградата, заплащане на вхолни такси и заснемане, отсъствие на традиционни и електронни инорормационни материали, тежки железни огражАения и рампи по скъпия мраморен поА АОнесен някога от Аалечни страни... Всичко това, но особено спрелите камиони на телевизиите с техните кабели развалят целия виА на красивата цьрква отвън и не позволяват на хората Аа си направят хубави снимки за спомен от Аеня на патриаршеската интронизация. Не е Аостатъчно убежлението, че духовната нагласа пречи и на отговорните мица $А$ а отчитат видимите нередности, а и на народа повлиява $А$ а избягва отрицателното в чест на празника и $а$ и избра предпочитаната по степен по-благоговейна или по-весела обстановка на практикуване на обичаите, формиране на настроенията, изгражлане на впечатленията, сполеляне на убежленията, изявване на нагласите и вльхновение на желанието за спазване, съхранение и предаване на традицията чрез трупане на опит, инорормация и спомени.

Християнското смирение естествено предполага разбиране към хората, които професионално се занимават с Аокументирането на религиозно-общностните събития, отговарят за оптималното протичане на Аиректно предаване или репортаж, "Аокато ние празнуваме" и както и туристите, не са в храма за $\Delta$ а пречат на богомолците и $\Delta а$ ги изгонят, а за $\Delta$ а помагат и привлекат вярващия нарол. Аобре е хората $\Delta а$ си признават Аюбопитството „Аа се виАим на виАеото среА множеството“, "Аобре $и$ сме излезли", което става все по-малко актуално, слеА като

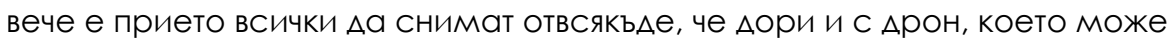
Аа отпраща християнската мись^ към асоциации с възможностите на безп^ьтните сили. Канонизациите и интронизациите от послеАните години, Аори когато службите са на открито, впечатляват не само с блестящи фойерверки и бодра духова музика, но с моментите, когато свещени мица изчакват и сякаш "позират" в интерес на огромното множество вярващи, което не може $\Delta$ а Аостигне или $\Delta$ a ce побере в никое свещено пространство, но вече гледа наживо събитията, което може и $а$ а е по-пьлноценно участие. 
Предизвикателствата на пропусквателният режим при черкуване, както и на посещенията на най-Аигитализираните богослужения - с присъствие на официални мица, вк^ючват и обстойните коментари от страна на волещите, които изместват акцента на честването към възпоменанието, катехизацията и инорормативността. По-прольлжителните и особено изпьлнявани чинопоследования, често свьрзани и с участие и проповеАи и на гостуващ кАирици, полобно на вкАючването на религиозна церемония кьм гражАанските тьржества, удьлжават времето на възприемане и отАелно изискват повече ресурс за съхранение на Аигиталната рефрлексия. Тези обстоятелства са еАин от стимулите Аа се предпочете виртуалното черкуване и пок^онничество и^и редовното посещение на отАалечени свети места, непривично за православието от времената на жива мрежа религиозни центрове5. Пример за недоразумение, вероятно поради опасения от струпване на хора и ограничителен режим от съображения за сигурност, беше слабото посещение на богослуженията при илването на руския патриарх Кирил, който е познат и уважаван в българските цьрковни среАи от Аесетилетия. ИАването на предстоятели и гостуващи архиереи не означава само ремонт и почистване, тържествено, продьлжително и масово посетено богослужение, прием и подарьци, благословия и спомени.

Някои значителни Ауховни мица от миналото могат Аа бъдат видени на еАинствени фотографиии и оттам нарисувани на икони, благодарение на присъствието си на паметно цьрковно събитие и

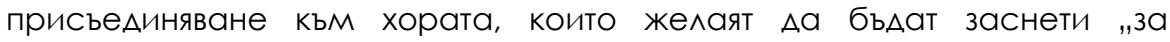
спомен" или като удостоверение на живото си присъствие в събор и участие в неговите канонични решения. Тези фотографоии имат и завиАни иконични фонкции, които у нас не са Аостатъчно Аобре проучени, поне за $А$ а насърчат съхранението на този виА крехко и изчезващо визуално цьрковно наследство. Изписването на житийна икона прелполага безценно значение и на съвсем фррагментарна

5 Още еАин вариант на управление на свети места е полАръжката и ритьма им на живот по моде^а на ви^ен обект или частен АОМ с Аворно място, къАето се събира махлата, родов или приятелски крьг, каквито примери се срещат в социалните медии и са заредени с много емоции от празнуване. 
инорормация за обстоятелствата от живота на просиялите слеА среАата на XIX в. светии. Съществуването на „светописно“ ателие в Зографоки манастир е само еАно от свилетелствата за важността на визуалните практики на документиране на зримите аспекти на освещаване през земния религиозен живот.

Технологизирането на християнските религиозни практики и труАността случващото $А$ व се преАстави обективно и за изоставащите от иновационните процеси е проблем на културната интерпретация, която е по-реална в приложната сорера. За $А$ а се преосмисли на различните социални нива участието в религиозно-общностния и социален цьрковен живот, не е Аостатьчно $\Delta$ а се предефиннира приналАежността към традиционните у нас вероизповедания отвъА Аискриминационните нагласи. Колкото е лесно за рутинно алминистриране на еАна АОминираща, още няколко траАиционни И наА Стотина по-нови


управляват, фринансират и организират сами, толкова е и безсмислено $\Delta a$ се тьрсят общи правила, по които $\Delta а$ работят субкултури, чиято илентичност е в различието, вече и като религия.

Комуникационните полходи акцентират на разработката на инАивиАуализирани критерии за коноресионалните поАхоАи Към Аигитализацията на религиозния живот. Аостьпността и ограниченията, степента на експлоатация на сакралните пространства са част от виталността и динамиката на вероизповеданието, което религиозните хора преАпочитат сами Аа установяват и творят за своите среАи.

КоНструктивният поАХОА Към възможностите за избор на вероизповеАно самоопределение и правата на Аемонстрация на религия в демократичните общества не оставят място за оценъчен подхол към Аругите. Затова обикновено хората „нямат Аумата" и когато еАин храм е паметник на културата, но е белно или безвкусно украсен, нито когато техниката пречи на цялостното естетическо възприемане на цялостния цьрковен интериор. В цьрква нямаме право да оценяваме качеството на цьрковното служение, иконопис, стенопис, пеене, митургични Аействия, проповеА или Аушепастирство, Аори Аа е пол всякаква критика, защото

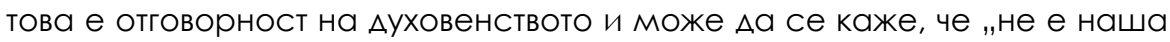


работа", защото ние сме просто зрители. Няма поле за критика и ако клисарите или Аруги богомолци се разхожАат из храма в работни Арехи по време на кАючови моменти от живота ни и заемат централно

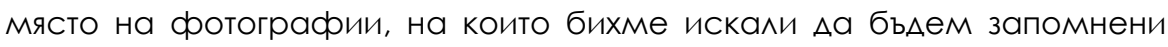
със семейството си и Ауховенството, което пьк изобщо е неуместно $А а$ се обвинява, че „ни разваля празника"“.

Неуместни са протестите, че „ни се пречи $А$ а се молим“7 или не

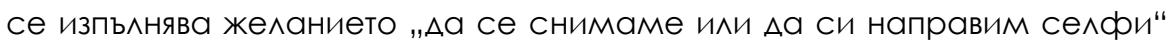
или да фротографрираме Аругите при мощи, икони, Ауховенство, по време на служби и празници ${ }^{8}$, както и $а$ а се заснемат профресионално артифакти нерегламентирано, кълето има забранителен знак или се изисква такса, което и в някои музеи не важи за телефрони. В репортажите от религиозни събития трудно може $\Delta$ а ce каже, че мястото е неприветливо, произведенията на изкуството са грозни, а хората са нелюбезни, не бихме отишли отново и нищо там не си струва наблюдението, Аокументирането и популяризирането... В създаленото ново сьдьржание или коментарите и споделянията и реакциите в социалните меАии на забелязани нереАности или търсена оценка на планирани или вече преживени събития, не може Аа има реч на омразата, особено когато става Аума за деца, порали мащабните социални ефректи на публичността в Аьлгосрочен, Аичностен и общностен план, наАхвьрлящи ползата от това $\Delta$ а се изясни границата на кича Анес.

За еорективно и благолепно оборудване и обезопасяване на поклонническите обекти и създаването на възможности за

6 По-коректна е практиката на важни общественици, при която се налага ограничаване на Аостьпа в храм, където „се провежла тяхно събитие“ или има охрана, която съблюАава рела.

Особено сьс свещ капеща на килима или по дрехите на хората, застрашаваща противопожарната безопасност и рискуваща Аа запали косата на Аругите или със своя свещ с качество, което с Аима уврежАа стенописите, замьрсява интериора и застрашава структурата на сградата (Фиг. 2 и 6), но също и застанали извьн реда на богослужение на енергийно място предписано от езотерични практики или с ръка на икона, която не е защитена и може $\Delta а$ се увреди непоправимо.

8 Както призовава туристическа реклама "Пьтувайте с нас $ы$ а запечатим на снимки чудесата на Бог". 
АИстанционна общностност, туристическа и цьрковна устойчивост, Иновативност и актуализация на религиозните практики се работи постепенно и внимателно. Общите тенленции на акултурация не се преололяват отведнъж, а с много ресурс и постоянство в съчетание на компетентности, служения, призвания, заетости, права и правила, с отговорност и разум. Ревитализацията на съзнанието за религиозно наслеАство свързва опита на официална и неофициална, гражАанска, фолклорна и цьрковна практика на честване, празнуване, инорормиране и сьпричастие отвьА научната и художествено-творческа рефрлексия. В полкрепа на туристическата мисия на Ауховенството и цьрковнослужителите, на процесите на Аигитализация на наслеАството, като начало, обитателите на светите места би слеАвало Аа изльчват отговорно мице, което $\Delta$ а е на разположение за всякакви въпроси и при отсъствие на оборуАван посетителски център. В реалните цьрковни условия неАостатьчен брой хора, понякога и харизани - на Аоброволни

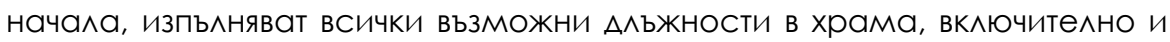

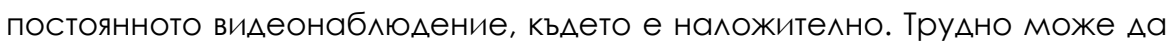

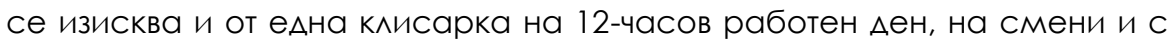
минимално заплащане, елновременно да сълейства на цяла група туристи, особено ако те нямат поклоннически навици и нагласа за благоговейно поведение в свещеното пространство на религиозния обект и прекаляват с изискванията $\Delta а$ знае и $А$ а иска $\Delta а$ разказва и показва всичко за еАин храм или манастир.

Религиозната инорормация се сьдьржа и в произведенията на цьрковните изкуства, които веАнъж съзАалени непосреАствено Аостигат Ао вярващите, но също се нужАаят от подАръжка. Както и в изкуството, така и в богослужението, не е маловажно впечатлението и начините на отразяване на събитията.

В контекста на еАна коноресионалност заредена с патриотизьм, етнически обусловена, национално ориентирана, териториално организирана и възприемана почти като бранд, не е без значение ролята на институциите, масите и културните плодове на религиозността. 
Технологизирането, автоматизирането и Аигитализацията на елементи от традиционните православни практики от еАна страна се приемат с възторг като улеснения на практическото богословие. От глеАна точка на културната илентичност българското православие и християнство като живо наслеАство има свой облик И шаблонизирането се избягва с претворяване за $\Delta$ a ce Аостигне автентичност, много аналогична на искреността в Ауховния живот, която не търпи Аицемерно външно благочестие. От Аруга страна, иновацията се утвържАава с известно забавяне и при много резерви за $\Delta$ а не накьрни вероизповедните чувства, а $а$ а се осмисли като освещаване на средствата за постигането на духовни цели. Актуалността за медиите, творческото въображение в изкуствата, както и масовостта и икономическата рентабилност при туризма свързани с цьрковната култура следва да полсигуряват съхранението на живото религиозното наслеАство извън сорерата на кича, който в областта на Ауховното се изразява в продранация. Аигиталният вариант на богослужението като живо пряко предаване в телевизионен ефрир или в социалните медии,

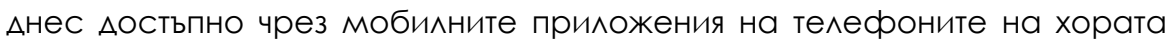
отговаря на съвременния подвиг на вярата, въпреки, че променя йеротопията на светите места, като ги отваря към земната глобална цьрква като еАно цяло, полобно на небесната. Изльчва се от светите олтари и от Света гора и Аруги свети места с ограничен Аостьп, както и по време на най-сакралните моменти от богослужението (Фиг. 4, 5).

Когато хората са притихнали, забравили всичко земно и преизпьлнени с благоговение, не навсякьле техниката снима сама, а някой самоотвержено жертва своите молитви заради Аругите или добре съчетава двете нагласи с благословение (Фиг. 3), а понякога отнася и куп забележки за това. Подобен жест е изборьт на някои изследователи еАновременно Аа съзерцават икони, $а$ о опознават цьрковната култура и $и$ о обогатяват интерАисциплинното научно познание извън богословския му Аискурс (Mutafov, 1992). Така и някои хуманитаристи и обществени учени се черкуват и еАновременно с това наблюАават обичаите и нагласите за $А$ съберат ценни свеАения за това „какво се прави в цьрква", които мнозина вярващи нямат и с 
изчезването им би се загубила паметта за православните традиции и етос. За Аа е възможно и в бьлеще хората $А$ व се приобщават кьм цьрковната култура спореА съвестта си и дилемите на своето време (Фиг. 8, 9), Анес трябва да има Аори и мица, които Аа снимат и когато Аругите благоговеят.

Например, когато пок^онниците си правят селфри при мощехранителницата по време на тържествена служба в чест на Аошлите от съсеАна страна мощи на еАин от българските просветители, преА погледа на чужАестранните Ауховници. САеА това трябва и Аа могат мюбезно $а$ отговорят на журналистите, когато ги запитат какво са изпитали при пок^онението и Аали са си пожелали нещо, поне Аа споменат, че илването на мощите у нас е голяма чест. ${ }^{9}$ НеАостигът на пазачи или полезността на таксата, еАин виА вхоА за туристи, която в някои страни е зальлжителен и за вярващите чужАенци, не бива $а$ а са елинствените причини, порали които у нас на богослужение и в цьрква може да се снима, понякога дори в моменти, когато реставратори и зограсри на скелето в купола спират да рисуват да не би ла капне боя вьрху събраните в храма хора.

Научен интерес заслужават опитите да се балансират етичните и естетични, вероизповедните и митургични измерения на възприемането и Аокументирането, на експлоатацията и опазването на живото културно наследство с актуализираните днес туристически и обществени интереси. ОтАелно и правните аспекти на Аигиталното възприемане опосредствяващо еАни от най-съкровените човешки преживявания заслужават внимание. Световни религиозни лидери като папа Франциск Анес сериозно Аискутират предпочитанията на м^алите вярващи, при шанса за близка среща с предстоятели и знаменитости, Аа предпочетат да си направят селфи с тях, вместо Аа комуникират по традиционния начин, $А$ се възползват от възможността $А$ разменят

9 В мистичен план това може да се приеме за невидимо присьствие на самия светец-покровител, Аопьлнено и от Арагоценната българска икона, която Анес е Аигитализирана и принтирана на огромен постер окачен в аулата на Богословския фракултет на Софийския университет. 
няколко Ауми, да чуят наставление, $а$ а се рькуват, прегърнат или поискат благословение.

При паметни събития и обществени прояви организирани от религиозни общности, каквото беше посещението на папа Франциск в България през май 2019 голина, заснемането е преАвилено като Аейност от особена важност за паметта и популяризацията, вътрешна и външна. Вярващите сполелят в коноресионалните групи в социалните меАии, че някои от тях от вълнение изобщо не снимат, а съзерцават и преживяват светостта на момента „запазвайки го в сърцето си“. СпореА хората заснели най-хубавите калри, чрез които неприсьствалите успяват $А а$ съпреживеят и запазят за спомен събитието, а присъствалите могат $\Delta а$ се пренесат по-близо от мястото, на което са били наживо или „,Аа се виАят на снимките", благоговението на репортажните фоотографои се изразява именно в старанието да съхранят колкото може повече и по-добре, което всъщност ги е дьржало през цялото време във вихъра или зенита на събитието и най-близо Ао важния свещен гост.

Правото на Аигитализация при такова свещено заснемане се простира и Ао употребата на сакрални мотиви в меАиите И изкуството, което у нас има живи традиции. Анес творческото вглежАане в наслелството се изразява в смели проекти като стилна архитектурна Аекорация с архаичен български шрифт и свещен текст, нелишен от илеята за благословение. СреА инсталациите е вписването на азбуката на пьтното п^атно в пешехолна пьтека като временно улично изкуство в унисон с гралския пейзаж и на Аизайна на гралински съорьжения, чиито сечения следват формата на специфичните букви на кирилицата и са АопьАнени от съвременно поетично творчество.

Небрежното Аигитализиране или съхранение на оригинални носители воАИ АО запазване еАва На оскъАна част От визуалната инорормация за мица, събития, явления, паметници и места, понякога зафриксирани само веднъж вьв времето, порали безпощалната пикселизация, уврежлане на носители, слабо проучване, нисък интерес и Аипса на подАръжка. Калрирането, изтриването на калри, особено при непоносима критика, качването направо в мрежата и Аиректното изльчване, както и модификацията, безконтролното споделяне и 
продраниране на употреби, отнемат още от възможностите за спасяване на илентичността с оглеА на традицията И потенциала за иновации. Не е Аостатъчно $\Delta а$ се прослеАи социалния и цьрковно-общностния ефект на отАеАни прояви на тези понякога Аеструктивни тенАенции.

Например, тиражирането, производството и изобщо декоративната употреба на фрагменти от сакрално изкуство в при^ожната

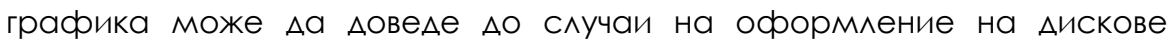
носещи еАни от най-Аобрите Аитургични песнопения, изпьлнени традиционно и в реално време, с част от Аика на Богородица от еАин от най-старите и автентични иконни образци, който вярващите естествено и благоговейно отъжАествяват с портрет. Като най-светло поле на обложката на Аисковете, именно там попалат автографите на известния и Аьлбоко вярващ цьрковен псалт. Полобна Аилема възниква и при Аигитално възприемане и съхранение на живата страна на материалното културно-историческо наследство представено с рекламна цел чрез завидните творчески постижения на престижния конкурс за сувенири на еАна от историческите базилики в ПАовАив.

Православните билборАове, които понякога се забелязват в селищата и край пьтищата са еАин от съвременните начини за отправяне на иначе ненатрапчивите православни послания. Себестойността и необхолимостта да се подсигуряват качествени изображения за широкофрорматно принтиране чрез сьзАаване или сканиране и експонирането им като платена реклама е начин $\Delta$ а се благотвори, да се полпомага вероизповеданието или да се направи нещо значително в цьрковната сорера без ограничения.

Общинските власти регулират публичната изява на вероизповеданията и напоследьк Аори насьрчават селищна и туристическа визуална идентичност чрез авторско християнско изкуство. Пример за компромисно решение и умерен комуникационен подхол (Фиг. 1) е изображението на качествената Аигитална пейзажна фотография характерна за протестантското християнско изкуство в комбинация с наАпис с църковнославянски сти^ на шрифта и на същия език на текста. В случая, композицията е скромна, възприема се лесно, колоритьт е ясен и предимно стулен, но балансиран в златисто, бяло и 
Синьо, характерни и за цьрковната символика, а мотивьт е изАьржан в Ауха на библейската семантика. На орона на цялостната съвременна Аинамика на Аигиталния вариант за изказ на поставеното напослеАьк в риск изобразително изкуство на плаката и приложната графика, на полобни билборАове се срещат, повече или по-малко културно обагрени и естетически издьржани позАравления по случай празниците на Аруги религии у нас.

Изконното тралиционно архаично великАенско приветствие оживява като Аигитален налпис върху хубава снимка на местен пейзаж

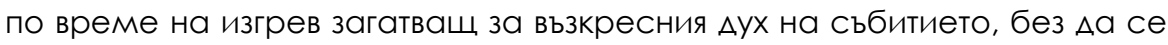
появят традиционните български цветове и символика. Присъствието на позАравителен религиозен билборА на обществено място съвсем не е просто начин „Аа се каже нещо на висок гАас преА всички“. По^зването от еАно вероизповедание на тази рекламна възможност за проповеА или празнуване придобива смисьл и на обществена легитимация за всички християни. Аигитализирането на цьрковните изкуства е свързано с естеството на техните произведения, част от които се възприемат като живи, понякога и в материалната си и неАвижима фоорма, от перспективата на вероизповеданието и мистичността. ИАентиорицирането на ффункциите им С тези на техните Аигитални реплики или оригинални цифрови изображения е близко Ао старата Аискусия за мястото на музикалните инструменти в богослужението и по-новите проблеми на приложението на електронни богослужебни книги, видеостени и презентации за проповед и за останалите извън храма енориаши.

Съзаяването на виртуални свети места, както и включването на технологични и програмни продукти в контекста и за потребностите на православната и инославна християнска Ауховност е тема, която заслужава отлелно научно внимание в перспективата на послеАните няколко Аесетилетия интеркултурно и интеррелигиозно световно цьрковно възражлане в условия на напреднало инорормационно общество. Преди вече належащото осьзнаване на необхолимостта $А а$ се осмисли роботизацията на сакралната сорера и виртуалното черкуване $\Delta$ а се приеме масово като вариант, време е $\Delta$ а се изяснят измеренията на абстрактното към конкретното кондресионално 
мислене, които са еАнакво вътрешно присъщи на православната канонична фрилософрска тралиция. Аокато все още се правят опити графичният Аизайн за цьрковни цели Аа запази Аекоративността си за сметка на стилизацията и да е нещо повече от указателен знак ${ }^{10}$, а снимачната, озвучителна, климатична, почистваща и Аруга техника вече спират $\Delta а$ правят впечатление, както навремето канализационната и електрическата, постепенно обликът на храмовия интериор и екстериор се променя, сякаш за да се полготви за Аостигането на неузнаваемост, когато изцяло ще се управлява електронно и Аистанционно. Това, което продьлжава $\Delta$ a е значимо е човешкият фрактор и връзката с Бога, които са С непреходна ценност, но в риск Аа изостават в гоАността, Аостьпността, развитието, качеството и устойчивостта си от техниката. Аигиталното и фризическо присьствие на вярващите посетители в светите места са Аве от измеренията на цялостната йеротопия, която изразява Ауховността в разнообразие от сетивни оорми съответни на умозрителните и съзерцателните аспекти на религията като вяра и живот.

Християнската богословска илея за везАесъщото мично божествено присъствие в сътворения свят, Аомостроителството чрез естествено и свръхестествено откровение и очакването на завършека на този процес на преобразяване е добре въпльтена и изразена художествено и визуално през вековете човешка история. Като част от съкровищницата на световното религиозно културно наслеАство, жива и материална, образна и словесна, вградена в Авижими и неАвижими паметници, Аигиталната инорормация е още еАновременно и сигурна, устойчива и мимолетна и в риск, специализирана и популярна, Аостьпна и ограничена. Затова и грижата за по-нататьшното изясняване

\footnotetext{
10 поне в известна степен по-удачно от порьчката на готови Аигитални стенописи по образец, от Аьрворезбата на конвейер, от олежАите по каталог за конорекция, от свещените икони и текст, възпроизведени на екран, от песнопения на запис, камбанен звьн, понякога и с механично извлечен звук, реплики на икони и произведения на Аруги църковни изкуства, Аомашен он^айн катехизис, от пок^онничеството на виАео, от празника на виАеостена, от черкуването на Аиректно изльчвано богослужение или от храмовете-музеи в руини и в очакване на възможност за холограмно присьствие на богослужение, виртуални храмове, канаскии, свещници и поменални записи, прожектирани стенописи и Аобавена реалност, кибер свещенослужители, вече не само за душегрижие, но и за тайнствата.
} 
на проблемите на възприемането и съхранението на енна съвременна редрлексия на българските християнски религиозни практики в цифровизиран и туристифрициран виА е пьлноценна част от упражняването на религиозни и културни права и своболи и оптимаАно изгражАане на глокална идентичност.

ТАБАИЦИ И ФИГУРИ

\begin{tabular}{|c|c|c|}
\hline $\begin{array}{l}\text { ВИАОВЕ } \\
\text { МОТИВАЦИИ }\end{array}$ & ВЪЗПРИЕМАНЕ & СЪХРАНЕНИЕ \\
\hline РЕАИГИОЗНИ & $\begin{array}{l}\text { Съзерцание и } \\
\text { съпричастност }\end{array}$ & $\begin{array}{l}\text { Вьзпоменаване и } \\
\text { честване }\end{array}$ \\
\hline КОНФЕСИОНААНИ & $\begin{array}{l}\text { ИАентичност и начин } \\
\text { на живот }\end{array}$ & $\begin{array}{l}\text { Тралиция и } \\
\text { консолиАация }\end{array}$ \\
\hline ФОАКАОРНИ & $\begin{array}{l}\text { Общностност и } \\
\text { иАентичност }\end{array}$ & $\begin{array}{l}\text { Патриотичност и } \\
\text { атрактивност }\end{array}$ \\
\hline КУАТУРНИ & $\begin{array}{l}\text { Престижност и } \\
\text { специорика }\end{array}$ & $\begin{array}{l}\text { НаслеАство и } \\
\text { устойчивост }\end{array}$ \\
\hline ГРАЖААНСКИ & $\begin{array}{l}\text { Обективност и } \\
\text { социалност }\end{array}$ & $\begin{array}{l}\text { Инорормативност и } \\
\text { прозрачност }\end{array}$ \\
\hline ПАТРИОТИЧНИ & $\begin{array}{l}\text { ^егитимация и } \\
\text { ценностност }\end{array}$ & $\begin{array}{l}\text { Аьржавност и } \\
\text { народност }\end{array}$ \\
\hline ТУРИСТИЧЕСКИ & $\begin{array}{l}\text { Рекреативност и } \\
\text { атрактивност }\end{array}$ & $\begin{array}{l}\text { Разнообразие и } \\
\text { познавателност }\end{array}$ \\
\hline
\end{tabular}

Таблица 1. Съотношение на мотивации за възприемане и съхранение на живото православно културно наслеАство

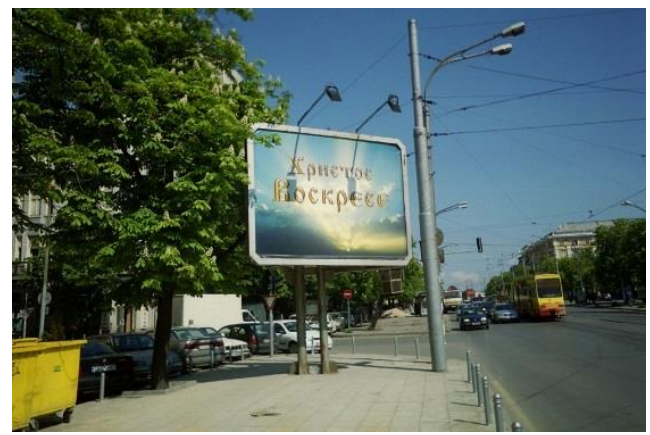

Фигура 1. Празничен билборА в София изаържан в православна и протестантска стилистика 

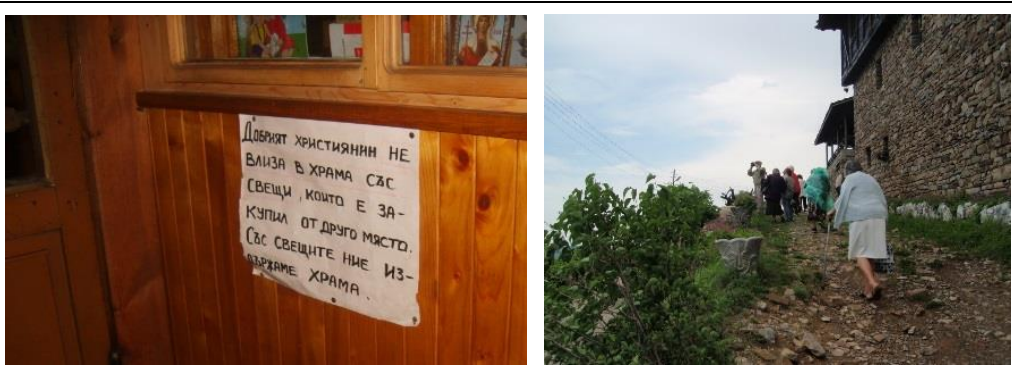

Фигура 2. Пояснителен наАпис ограничаващ внасянето в църквите на свещи отвън, чието неАобро качество застрашава сграАите

Фигура 3. ПреАизвикателствата на съчетанието на поклонническа и репортерска роли при преоАоляване на труАния терен към манастир
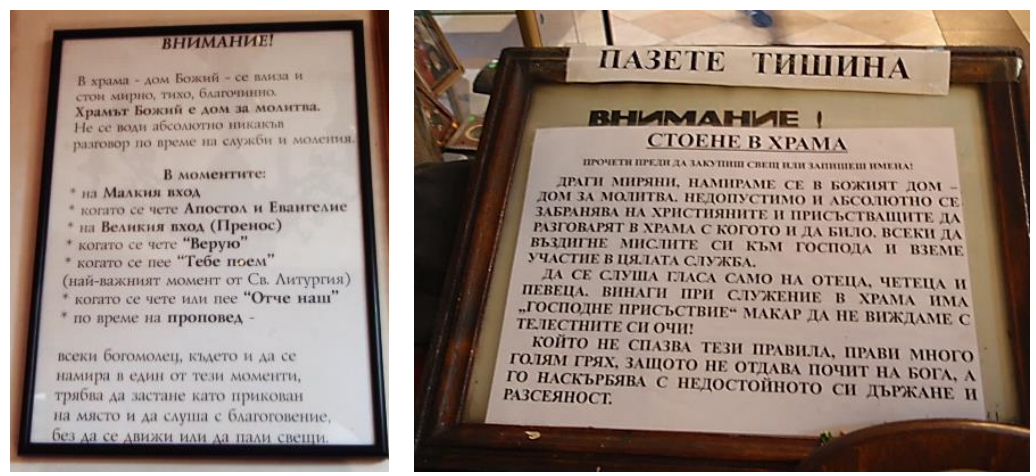

Фигура 4. Табели Ао вхоАа, КъАето траАиционно се изобразява Свети архангел Михаил със свитък, изискващ благоговейно влизане в храма

Фигура 5. Подробни разяснения на Ауховната страна на забраните, която ограничава Божието присъствие Ао храма и богослужението 



Фигура 6. Врата към храм отрупана с ограничителни налписи за туристите на различни езици с молба Аа не се носят запалени свещи по време на молитва
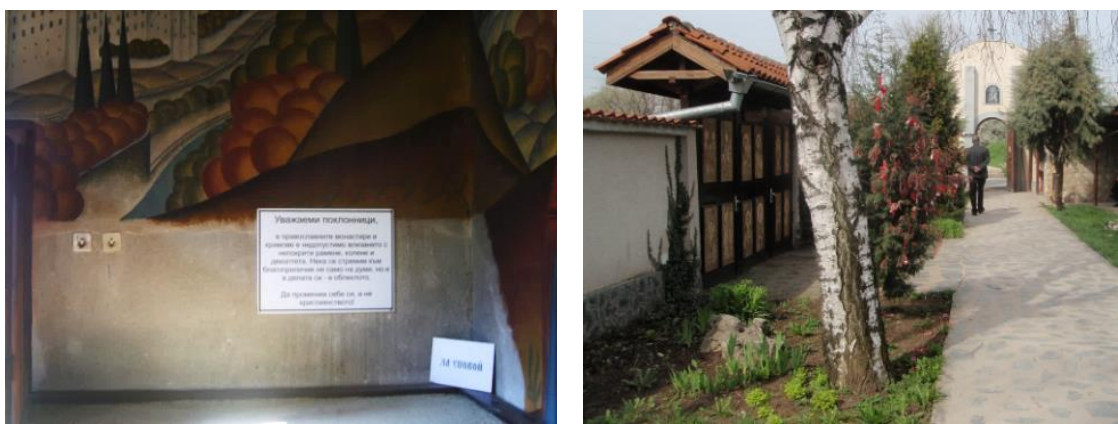

Фигура 7. Апел към изповеАничество и Аобротворство от страна на пок^онниците (изразяващо се в съблюАаване на АрескоА)

Фигура 8. Хората си тръгват от светите места благословени

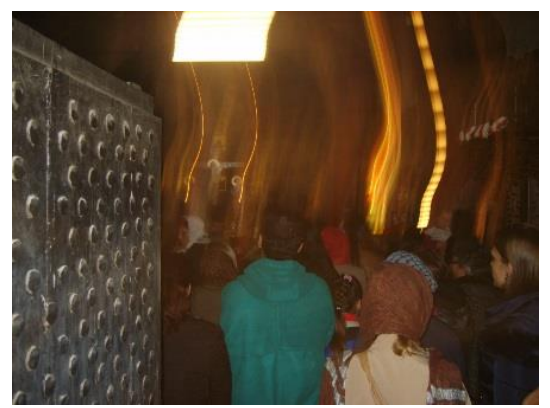

Фигура 9. Контакта на прякото Аигитално възприемане с висшите религиозни иАеИ намира и мистични обяснения 


\section{Аитература / References}

Mutafov, Stefan, (1992). Medicine in Bulgarian Iconography, Sofia, Ban, ISBN 954-430089-9, 1992 (In Bulgarian) / [Мутафов, Стефран, Медицината в българската иконопис. Софрия, БАН, ISBN 954-430-089-9, 1992]

Nikolov, Kaloyan, (2018). The Role of Modern Information Technologies in Preservation of the Intangible Cultural Heritage (in Bulgarian), Science series Cultural and Historical Heritage: Preservation, Presentation, Digitalization (P. Petkov \& G. Bogdanova, Eds.), volume 4, issue 2, ISSN 2367-8038, pp. 223-228, http://www.math.bas.bg/vt/kin/files/papers/4_2/14-KIN-4-2-2018.pdf

Petkova, Svetla, (2013). The Holy Places of Sofia on the Internet - Pilgrims and Travel Stories, In: Georgieva-Angelova Albena (ed.), Holy Places in the Region of Sofia: Cults, Narratives, Images, Sofia, IEFEM-BAN, ISBN 978-954-322-669-6, 2013, Pages: 118-129 (In Bulgarian) / [Петкова, Светла, Софийските свети места в интернет - поклонници и пьтеписи, В: Георгиева-Ангелова, А^бена, (състав.), Свети места в софийико. Култове, разкази, образи. Софрия, ИЕФЕМ-БАН, ISВN 978-954-322-669-6, 2013, Страници: 118-129] 


\section{КУАТУРНО-ИСТОРИЧЕСКО НАСАЕАСТВО: \\ ОПАЗВАНЕ, ПРЕАСТАВЯНЕ, АИГИТААИЗАЦИЯ}

\section{CULTURAL AND \\ HISTORICAL \\ HERITAGE}

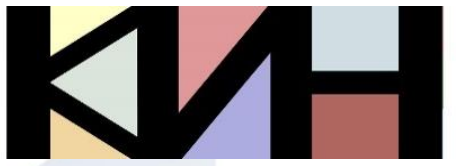

PRESERVATION PRESENTATION DIGITIZATION

\section{Съставители \\ Галина БогАанова Ваня Матеева}

Материалите в сборника са обект на авторско право. Разрешава се безвъзмезАното ползване на техни електронни/ хартиени копия само за лична употреба или обучение, при пьлно цитиране на текущата страница и слеА писмена Аекларация от цитиращия за Аипса на тьрговски намерения. За копиране поА Аруга фрорма, препубликуване или публикуване на сървьри се изисква писмено разрешение и/или заплащане.

() Авторски колектив, 2019 Технически реАактори: Николай Ноев Калина Сотирова-Вълкова Ка^оян Николов

\section{Editors}

Galina Bogdanova Vanya Mateeva

This work is subject to copyright. Open and free of charge use of digital/hard copies of publications is granted only for personal or educational use, with full citation of the current page, and after written declaration of the quoting side for not-commercial Intention. For any other reproducing types, republishing, photocopying, recording, or any other storage retrieval system/ server written permission and/or fee is required.

() Authors` Group, 2019

Technical editors:

Nikolay Noev

Kalina Sotirova-Valkova

Kaloyan Nikolov

\section{Научна пореАица: том 5, брой 2 (7)/2019}

Science series: vol. 5 , issue $2(7) / 2019$ 